\title{
The Inevitable Trend and Challenges Faced by Bilingual Teaching in Management Science
}

\author{
Yifan Zhang \\ College of Humanities \& Sciences of Northeast Normal University \\ Changchun City Jilin Province 130024
}

Keywords: Management science; Bilingual teaching; Trend; Challenge

\begin{abstract}
Along with the progress of China`s internationalization and outward-oriented development, new research topics of the Management Science, which is an academic discipline of the study permeating all levels of a commercial society, have been put forward among national educational institutions and colleges and universities offering the academic discipline-whether it's necessary to promote the bilingual teaching in management science, if yes then how to do it, what difficulties will be faced in doing it, and how to deal with those them.
\end{abstract}

\section{Introduction}

The acceleration of the progress of world economy integration and globalization led by China`s entry into WTO, along with the leaping development of public transportation and information technology, has a direct or indirect influence on the advance of the outward-oriented development of China`s social and economic activities.

In the first ten years of 21 st century, the outward-oriented economic entities, including both sole proprietorships and joint ventures, had grown to enormous proportions, spreading from first-tier cities to the second-tier and third tier cities in an increasingly fast speed. The importance of language skills, especially the English communication skills, have become more and more manifest in the workplace of business field. At the same time, it has facilitated the trend of bilingual teaching among many majors in colleges and universities, gradually becoming the hotspot of educational reform.

The conflict between continuously expanding demand, the lack of resources, and the limitation of the existing educational system, is a burning issue on the table of educators.

\section{The Inevitable Trend of Bilingual Teaching in Management Science}

The Conflict between the Existing Foreign Language Teaching System in Colleges and Universities and the Demand from Job Market. The foreign language teaching system existing among colleges and universities in China can be divided into two major types, one of them is the language teaching in an academic manner, based on which, courses with an accent to linguistics and literature will be offered, without giving students the opportunities to use the language for social practice, in which way, the graduated students are likely to be only capable of talking about simple subjects in English, or translating text materials on simple subjects into Chinese, when it comes to a professional subject needed to be dealt with, they will be at loss what to do, which makes the recruiters worried after bringing them in; the other one is that, the foreign language course for the students whose major is not foreign language is usually English course, and their study will be usually tested by CET 4 and CET 6, the contents in their English textbooks are usually about linguistics and literature on a basic level, the level is far lower than that for English majors. in which case, the foreign language teaching has basically been separated from professional courses, making the role of foreign language in the process of learning the specialized courses negligible, let alone to improve students` ability to talk about the professional subjects in English. Foreign language, as a commonly required course, fails to be taken seriously by many students, few of whom will have a comprehensive ability of the language in terms of listening, speaking, reading and writing after their graduation. In addition to the two cases above, some colleges and universities are trying out the ma- 
jor of Business English, the teaching method of which has made an advance in developing language skills for social practice, but the emphasis is still on the language instead of the professional knowledge, in which way, it might put extra difficulties on the graduates to move up to the senior management posts in the company they would service in.

\section{Internal and External Analyses of the Inevitable Trend of Bilingual Teaching in Management Science.}

Internal Analysis of the Trend of Bilingual Teaching in Management Science.

According to the related data issued by the State Statistical Bureau, the proportion of foreign investment in GDP has already exceeded 40\% in 2004; the analysis of employment situation in 2010 says that " the service sector has the potential to expand the employment by increasing the most posts". The demand for high-end talents whose job may involve foreign affairs is huge, the involved job fields include foreign-affair-related accounting, foreign-affair-related legal service, foreignaffair-related financial service, simultaneous interpretation, e-commerce, digital media, logistics, actuarial service and psychological counseling service, the shortage of the talents is expected to be 3.25 million. [1] The job fields mentioned above, especially those involving economy, require the knowledge of management science.

"The famous company of Mckinsey has predicted that, in the five years to come, the demand for the talent with both professional knowledge and language skills will be huge. It's a indisputable fact that China will need a huge amount of highly-educated technical talents who are good at speaking a foreign language. The inability to speak a foreign language is the disadvantage of the inservice technical staff. As for the students in colleges and universities, the most of them cannot speak English fluently, which is the major factor leading to the lack of competitiveness of technical staff in the international job market."[2]

Except for foreign companies` demand for bringing technical staff who can speak both Chinese and English into their bilingual management system, more and more domestic companies also need those talents to help them expand their business overseas, and it's obviously unrealistic to look to professional interpreters to expand overseas markets and manage the overseas companies.

Along with the constant update of teaching staff in all the colleges and universities, more and more highly-educated overseas returnees have selected the teaching occupation, facilitating the promotion of bilingual teaching method ( especially in English which is the universal language); in recent years, the efficiency of bringing in the textbooks written in English from other countries has been improved tremendously, some major domestic publishers, such as Tsinghua University Press and China Machine Press, have introduced textbooks of management science written in English, providing an easy access to those materials for both teachers and students.

1.2.2 External Analysis of the Trend of Bilingual Teaching in Management Science.

China and India are widely held to be the two "workshops of the world", however, in the competition between these two countries, India has an advantage over China-English. English is one of the official languages of India, which has attracted many companies in western countries to establish branches in India due to the shared language helping them to avoid misunderstanding because of poor translation, in which case, the management efficiency will be improved.

With the development of economy, China wants to convert itself from the "workshop of the world" into the "factory of the world", however, it`s impossible to train all the technical staff into the talents mastering two languages, therefore, the institutions for higher education should take the responsibility to help the students with technical skills or management knowledge to develop their foreign language skills.

In conclusion, it's imperative to realize the bilingual teaching in management science, the trend of our time leaves us no other choices, not to advance is to drop back! 


\section{The Challenges Faced by Bilingual Teaching in Management Science}

\section{Requirements of Qualified Teachers}

The realization of the bilingual teaching in management science cannot be separated from the qualified teachers who are not only equipped with professional knowledge of management science, but also proficient in English, and they are the very talents needed for higher education in China.

In China, there re more than two thousand colleges and universities, and few of them have the teachers who are highly-educated overseas returnees and capable of teaching the professional knowledge in English, and the rest them, however, is not able to meet this requirement yet. In order to apply the bilingual teaching method in management science, many colleges and universities have lowered the requirements in terms of professional knowledge or English language ability when they`re recruiting new teachers, the teachers who can reach both requirements are very rare.

\section{Requirements of Students`Abilities.}

The existing foreign language teaching system has attached an importance to academic knowledge, reading, and writing, with the neglect of practical skills, listening comprehension and speaking, in which case, a gap will be left between students` linguistic knowledge and applying the knowledge to their major of Management of Science. The requirements of the exported textbooks on the students in terms of listening and speaking are a challenge for all of them, especially those from nonkey educational institutions.

\section{Requirements of Textbooks.}

There`s quite a number of quality textbooks written in English introduced into colleges and universities in China, however, on one hand, the length of these textbooks is longer than similar textbooks published in China, therefore, extra burdens have been added on the teaching task, and teaching time has to be extended, and teaching cost has been increased; on the other hand, although the contents in those imported textbooks are always kept up with the advance in the academic field, but the cases put up in those textbooks cannot match the domestic situations, which requires the teachers to add more cases into their classes and translate them into English, leading to more difficulties in the process of teaching.

\section{The Balance between Two Teaching Objectives.}

The purpose of using a foreign language to teach specialized courses is to help students to have a full understanding of the professional knowledge while ensuring that they will be able to use English to deal with issues in their professional field, these two objectives, even one of them, are not easy to be achieved. How to help the students to accomplish these two learning tasks is challenge for educators. How to maintain the balance between fulfilling students' potentials and not deterring them by too high expectations is another challenge that we're facing.

\section{Judgement of the Trend of Bilingual Teaching in Management Science and Advice for Its De- velopment.}

\section{Judgement of the Trend.}

The realization of bilingual teaching in management science is an inevitable trend because of the demand in both domestic and international job markets and the development of higher education in China Integration with international development, which is needed for globalization, is a constructive and progressive objective. Globalization refers to not only the economic globalization and political globalization, but also the educational globalization, which should be the basis for other developments. So, the question is not if it`s necessary to realize bilingual teaching, but how to realize bilingual teaching 


\section{Advice for the Development of Bilingual Teaching in Management Science}

The faculty should be updated by bringing more qualified teachers, sending the teachers abroad for further education, and providing them with in-service training. The new teachers brought in should be English language teachers, highly-educated overseas returnees, or those who have both professional knowledge and English language skills; the teachers sent out for further education should be the teachers who have the potential, or administrative staff; the teachers receiving inservice training should meet related requirements. The costs of training and further education should be borne by the school and the teacher, which is good for the long-term development for both sides.

Key educational institutions can adopt full-English teaching method, i.e. using textbooks in English, and using English to teach specialized courses, making the writing on blackboard in English, asking students to interact with teachers in English and to finish homework and tests in English.

Non-key educational institutions can adjust the teaching method mentioned above according to the condition of their faculty and students, or adopt mixing bilingual teaching method ( using textbooks in English, assigning homework in English, making the writing on blackboard in English, and using Chinese and English to teach specialized courses), or adopt semi-English teaching method (using textbooks in English, making the writing on blackboard and assigning homework in English and Chinese, and using Chinese to teach specialized courses). [3]

The remuneration of the teachers should be in proportion to their capability and efforts put into the bilingual teaching task.

\section{References}

[1] The Spearhead of First Attempt in the Employment Situation in 2010, Baidu Wenku, 2010-5-11. [2] The Spearhead of First Attempt in the Employment Situation in 2010, Baidu Wenku, 2010-5-11.

[3] Weijian Huang, Fei Wang, Wei Du, Rational Thinking on the Bilingual Teaching among Key and Non-key Colleges and Universities, Journal of Hebei Institute of Architectural Science \& Technology (Social Science Edition), 2004. 